\title{
A Century of Geology.*
}

\section{By Prof. J. W. Gregory, F.R.S.}

7 HE geological problems of special interest in 11831 are shown by the contributions prepared at the request of the British Association, with first amongst them Conybeare's "Report on the Progress, Actual State, and Ulterior Prospects of Geological Science". His report summarised the position in general stratigraphy, which was still based on two divisions-the primary and the secondary. The secondary group, thanks to William Smith, had been classified into four systems-the Carboniferous including the Old Red Sandstone, the New Red Sandstone, the Oolitic, and the Cretaceous. All below the Old Red Sandstone was left as the primitive and transition series. The pre-Carboniferous and post-Cretaceous beds were still in confusion, but Conybeare's section from the north of Scotland to the Adriatic near Venice shows that the general succession had been established from the Tertiary to the Carboniferous and Old Red Sandstone.

The first great stratigraphical advance after 1831 was Lyell's classification in 1833 of the postCretaceous strata. Lyell's achievement was followed by the foundation of the Silurian system by Murchison. Murchison, in 1834, showed that the 'Upper Grauwacke Series' included four fossiliferous series, which in 1835 he grouped as Silurian. Sedgwick, a month later, in a communication to the Association at its Dublin meeting, founded the Cambrian system for the fossiliferous rocks below the Llandeilo and the schists of Anglesey and Carnarvonshire.

The fundamental advance in geology in the decade beginning 1830 was Lyell's demonstration of the uniformity of geological dynamics. The first volume of his "Principles" was published in 1830, and Murchison hailed it as "beginning to unfold the true papyri of geological history".

A different estimate was expressed by Adam Sedgwick, then the leader of British geology, who declared that Lyell's championship of uniformitarianism violated sound reasoning on geological phenomena, and that

"warped by his hypothesis ... in the language of an advocate, he sometimes forgets the character of an historian". According to Sedgwick, if Lyell's views of the uniform order of physical events were correct, "the earth's surface ought to present an indefinite succession of similar phenomena. But as far as I have consulted the book of nature, I would invert the negative in this proposition, and affirm that the earth's surface presents a definite succession of dissimilar phenomena. If this be true, and we are all agreed that it is, ... then 'the undeviating uniformity of secondary causes', 'the uniform order of physical events', 'the invariable constancy in the order of nature ', and other phrases of like kind, are to me, as far as regards the phenomena of geology, words almost without meaning. They may serve to enunciate the

* From the presidential address, entitled "Problems of Geology Contemporary with the British Association ", to Section C (Geology) of the British Association, delivered in Iondon' on Sept. 24. propositions of an hypothesis ; but they do not describe the true order of nature."

Sedgwick agreed with Brongniart that the geological and historical periods were essentially distinct; and he remarked regarding the recent appearance of man, "were there no other zoological fact in secondary geology, I should consider this, by itself, as absolutely subversive of the first principles of the Huttonian hypothesis ".

Murchison, on the contrary, held that Lyell's demonstration of the unbroken transition between the Pliocene and post-Pliocene had completely swept away the arbitrary demarcation between "what had been termed the ancient and existing orders of nature".

The geologists of 1831 worked under the handicap of three fundamental uncertainties. The problem of sea-level so exercised the Geological Committee in 1831, that it asked Robert Stevenson - the authority on coastal engineering and grandfather of R. L. Stevenson-to report upon the erosion of the English coast and "the permanence of sea-level ". He replied that he had little to add to his previous papers (1816 and 1820). The variability in sea-level is of perennial interest as many issues depend upon it. The test case about 1830 was that of the Baltic. Celsius in the eighteenth century had remarked that the Baltic was receding along the Swedish coast; but, as the German coast had undergone no such change since Roman times, the Swedish evidence was doubted. Leopold von Buch reconciled the observations by the hypothesis that the Swedish coast was rising about a pivot, while the German coast remained stationary. The facts were reaffirmed by a joint inquiry of the Swedish Academy of Sciences and the Russian Ministry of Marine; but the rise of the land was rejected by Lyell. He attributed the recession of the sea to the accumulation of sediment and the wind.

Lyell fortunately examined the evidence for himself, and in a paper read to the Association in 1834, accepted von Buch's conclusion that parts of the Baltic coast are rising two to three feet in a century, while other parts are stationary.

The Baltic, therefore, gives convincing testimony of the mobility of the land, which is accepted in an extreme form by some champions of isostasy. That principle was put forward from the geological evidence that the rate of the accumulation of sediments so often coincides with the rate of subsidence that the two processes must be dependent, the weight of the sediment being the cause of the subsidence. The correlative, that the unloading of an area by denudation causes its uplift, was advanced by Clarence King (1876). This cause of the rise and fall of land was maintained by Airy and Pratt, and was supported by the gravity surveys by Hayford, Hecker, and Duffield. The relief of the earth was attributed to the differences in the No. 3238, VoL. 128] 
density of the crust, and therefore the subsidence of the crust to form oceanic basins, and its uplift into continental masses from oceanic depths would be both impossible. That theory was of service as a reaction against the lightly assumed interchange, as pictured by Tennyson, of roaring streets and central seas; but the form of isostasy that represents the earth's major relief as determined by the perfect hydrostatic equilibrium of the crust is opposed to weighty evidence.

The mathematical data for the permanence of the ocean basins seem unreliable. That the ocean floors consist of a continuous sheet of heavy material (sima) was supported by gravity determinations ; but the calculations are based on the assumption that the sea surface stands at the spheroid of reference.

That some parts of the crust are in such delicate isostatic equilibrium that the surface rises when material is removed by denudation and sinks when loaded with more sediment is well established; but other parts of the surface have not this delicate poise. Faults have a downthrow of 10,000 feet, and there is no evidence that their cause was sedimentation. The dependence of subsidence and sedimentation may often be true for the geosynclines, which, owing to the rupture or instability of the crust in consequence of its deformation, are bands of long-continued weakness-or asthenostrophes (weak bands or belts).

Reluctance to accept the hydrostatic equilibrium of all parts of the crust is not due to prejudice against isostasy. But its extension to the whole surface of the earth and the claim that it proves the subsidence of an area to an oceanic depth to be a physical impossibility are contradicted by geological evidence, which appears more reliable than calculations based on uncertain assumptions.

\section{The Fixity of Species.}

The second hindrance to geological progress in 1831 was the belief in the fixity and special creation of species, which was then entrenched by theological authority.

The fixity of species had been attacked by Lamarck, but his view of the evolution of one species into another was emphatically rejected by British authorities. Buckland, who was the president of the Association at its first full meeting, denied that he was in any way disposed to favour Lamarck's theory of " the derivation of existing species from preceding species by successive Transmutations of one form of organisation into another form, independent of the influence of any creative Agent". Sedgwick repudiated "the doctrines of spontaneous generation and transmutation of species with all their train of monstrous consequences" The latter doctrine, with all its momentous consequences, was added to the principles of geology by a recruit of 1831 . Early that year, Charles Darwin began the study of geology, and on his return from his first long geological excursion, which he made with Sedgwick in North Wales, received the invitation to go as naturalist with the Beagle. He sailed in her from Plymouth in December 1831.

Darwin's work on the voyage was mainly concerned with volcanic rocks, with gravity differentiation in molten rocks, with uplifts accompanying earthquakes, and with the evidence of widespread areas of subsidence and uplift as proved by his luminous and now firmly established theory of coral islands. His work on crustal movements was of primary importance; but by his doctrine of evolution by natural selection, he was the most potent influence on the thought of the Victorian era. According to the general interpretation of the geological record, evolution has been mainly controlled by the environment, and has proceeded slowly during the long periods of relative quiescence and more quickly when the tumultuous heaving of the crust produced relatively rapid changes in the physical conditions, as in the depth of the sea, in the temperature of sea-water, and in climate owing to the altered distribution of land and water and relief of the land.

The influence of Darwin on the whole philosophy of geology was so helpful that he was the dominant factor in its progress during the second quarter. century of the Association's work.

The geological point of view of the day as regards the relations of geology and theology was shown in Buckland's " Bridgewater Treatise" $(1836$, p. 414). He argued that zoophytes show such perfect unity of design that we can find no explanation of such otherwise mysterious uniformity than by referring it to the agency of one and the same creative intelligence. He extended this argument to the whole organic world. The persistence of the same structural plans and the absence of those freak animals which might be expected if animals had arisen by special creation -instead of being regarded as evidence of evolution-was claimed by Buckland as proof of special creation by one Creator.

Buckland, though he defended the creation of man at 4004 B.c., and declared in regard to the six days of creation, "I see no reason for extending the length of any of these beyond a natural day ", was, nevertheless, too heterodox for some members of the Association. His view that the earth is indefinitely older than the creation of man was vehemently attacked by Dean Cockburn, the Dean of York, in 1838, and at the meeting of the Association there in 1844. It was not until about thirty years later that geology secured the independence claimed in 1832 by its doughty champion, Murchison, in his assertion of the "entire disconnexion of our science with the inspired writings".

\section{The Origin of Ore-Deposits.}

The third geological problem to which the Association directed attention was the nature of oredeposits.

The classification of mineral veins in 1791 by Werner attributed them to the filling of fissures from solutions. Hutton, in 1795, declared the deposition of native metals from solution a

No. 3238, VoL. 128] 
"physical impossibility", and that sulphide ores could only be formed at high temperatures. In 1831 , in reaction from such speculations as to genesis, the standard classifications relied on the form of the deposits ; Taylor rejected the formation of lodes by igneous injection and attributed ordinary ores to sublimation. As many mineral veins were too wide to have been formed by the infilling of open fissures, the electric deposition of the ores was advocated by R. W. Fox in papers to the Association. Ami Boué, in 1822 and 1829, supported the general association of mineral veins and igneous rocks, and A. L. Necker also urged, despite a few apparent exceptions, the general "connexion of igneous with metalliferous deposits ".

In 1835 the main alternative explanation-the connexion of mineral veins with great fractures-was put forward by J. Fournet. He assigned the minor veins to the filling of shrinkage cracks and small faults ; and the veins of most economic value, to deposition along major faults.

That the ores along these fractures were due to rising waters was rendered the more probable by the paper contributed by C. G. B. Daubeny at the 1836 meeting on "Mineral and Thermal Waters". Meanwhile, the theory that ores were derived from waters percolating through the rocks beside the veins had been revived by Bischof (1847), but was generally rejected until Forchhammer and Sandberger found particles of the ordinary ore metals in all kinds of ancient rocks.

The ascensionist was then replaced by the lateral secretion theory, which was dominant for twenty years, until in 1893 the deep-seated source of most ores was advocated by Posepny. An intermediate view, advocated by Kemp, redirected attention to the general association of mineral veins with igneous rocks; and the view that the constituents of the lodes are derived from igneous rocks is perhaps still the generally accepted theory. There are serious objections to it : for though many metals occur in the igneous rocks, the quantity appears insufficient to have furnished the lodes. Many of the claims for the presence of such metals as primary constituents of igneous rocks are invalid. The distribution of ores indicates their derivation from a layer below the igneous rocks.

The deep-seated source of ore-deposits bears on the geology of the inner earth, which was exercising geologists in 1831, when amongst subjects recommended for examination were the "accurate examination of the conclusions deducible from the known density of the earth, as to the solid structure and composition of its interior", and "the examination of the visible disk of the moon, with the view of extending cur general knowledge of volcanic forces ".

When the efforts to correlate the main relief of the earth were resumed, the most stimulating worker was Élie de Beaumont. His correlation of mountain chains was based on the view that the interior of the earth is slowly cooling and contracting so that the outer shell undergoes alternate deformation and recovery of the spheroidal form. He concluded that these crustal movements account for the mountain ranges and main relief of the earth. He realised that the crust is a unit which is affected as a whole by each of the orogenic episodes which upheaved mountain systems at the same date in even distant parts of the earth. $\mathrm{He}$ held that fold-mountain chains of the same orogeny are recognisable by their trend, and classified the mountains of Europe into four systems, each with a characteristic trend. As the trends were determined by the fracture of a spherical or subspherical shell, he considered that they would be on a regular geometrical pattern.

f́lie de Beaumont's views attracted earnest attention, and at the first meeting of the Association Sedgwick and Conybeare were asked to report whether his maxim that mountain ranges with the same trend were of the same age holds true for the British Isles. Sedgwick replied that the older British strata are in strict accordance with Élie de Beaumont's theory, and expressed enthusiastic approval of it in his presidential address to the Geological Society. He declared-

" that the system of M. Élie de Beaumont is directly opposed to a fundamental principle vindicated by $\mathrm{Mr}$. Lyell cannot admit of doubt. And I have decided, to the best of my judgment, in favour of the former author, because his conclusions are not based upon any a priori reasoning, but on the evidence of facts ; and also because, in part, they are in accordance with my own observations."

Conybeare was more critical of Élie de Beaumont's theory. He objected to describing the Urals and the American Cordillera as parallel, and held that the correlation of English folds by parallelism is unsatisfactory.

Élie de Beaumont's work laid the foundations of the modern study of the general plan of the earth. His fundamental principles were that the main movements in the earth's crust are due to its compression owing to the shrinkage of the internal mass, and that the collapse of the crust determines the main features in the relief of the globe. The shrinkage is probably due more to closer packing of the constituents than to cooling. That the main folding of the crust has been due to compression that at first acted on all parts of the earth, and later was confined to special belts, seems one of the most certain of geological facts.

Élie de Beaumont unfortunately adopted as the basis of his fold-and-fracture pattern the pentagonal network, which had to him the recommendation of its possession of a high degree of symmetry. The most obvious fact in the map of the world is that it has no such highly developed symmetry.

I endeavoured to show in 1899 that Lowthian Green's theory agrees with the existing distribution of ocean and continent, and with geological history, as it explains the alternation of the slow subsidence of the ocean floors and of crustal storms during which fold-mountain chains are raised by lateral compression ; it also explains the alternate emergence of the lands as the ocean basins are enlarged by the sinking of their floors and submergence of the lands by the world-wide advance of the sea due to the shallowing of the oceans when the spheroidal 
form is recovered after the tetrahedral deformation has exceeded the stability of the crust.

Élie de Beaumont's elaborate classification of mountains has collapsed ; for although the foundations were sound, his superstructure was not. Knowledge of the structure of mountain chains was then inadequate and much of it was erroneous. Beaumont's conception of mountains was defective; he regarded them as symmetrical ridges, and he failed to appreciate the contribution to the Association in 1842 by Henry Darwin Rogers, which laid the foundation of the modern theory of mountain formation. In 1842 Rogers read to the Association his joint paper with his brother, W. B. Rogers, "On the Physical Structure of the Appalachian Chain, as exemplifying the Laws which have regulated the elevation of great Mountain Chains generally". The Rogers considered the facts at variance with Élie de Beaumont's hypothesis. They explained mountain chains as waves in the crust due to a broad belt being pushed forward with accompanying asymmetric folding, overfolding, and inversion.

Suess showed that the existing physiography of Europe was mainly due to the Alpine System-including the Pyrenees, Alps, Carpathians, and Balkans-having been pushed northward against resistant masses which threw back the waves like forelands along a coast. Suess had the advantage over the geologists of the 'thirties of more certain petrology. They still worried over the igneous origin of granite, and even a decade later were at issue as to whether granite had been injected as a molten mass at a high temperature, or was due to aqueo-igneous action at a low temperature.

A great advance in the interpretation of the igneous and metamorphic rocks followed Sorby's application to them of the microscopic study of transparent sections. He announced its illuminating results to the Association at Leeds in 1858, showing that the crystals and bubbles in the fluid cavities in granite prove its deep-seated origin, and that the Vesuvian lavas demonstrate that the sequence of minerals in igneous rocks is determined not by their fusibility but by their order of crystallisation out of a cooling solution.

The interpretation of mountain structure had an important reaction on stratigraphy. Suess's study of world geology led to the recognition that some encroachments of the sea upon the land were worldwide; he called them the marine transgressions, and explained them by the reduction of the ocean basins.

Many cases of the rise of the sea surface may be due to changes in the ocean basins and not to a vertical uplift of the land. Suess regarded some high-level horizontal beds as left in their original position by the down-sagging of the crust elsewhere. He was so impressed by the predominance of downward movements in sunklands, rift-valleys, and oceanic deeps, and by the absence of any mechanism which he regarded as adequate for widespread horizontal uplifts, that he considered all vertical regional movements must be downward. In this he went too far; but that the land sometimes emerges owing to lowering of the sea surface, and at others is submerged by the rise of the sealevel, is now universally admitted.

In 1831 Conybeare dismissed the stratigraphical principle, "Werner's dogma. of Universal Formations", as he held that in distant lands corresponding formations are not synchronous. This idea, also adopted by $H$. D. Rogers in a paper to the Association in 1834, was a forecast of Huxley's doctrine of homotaxis, which is less important now that as much time is available as the greediest geologist can desire.

The zonal divisions, however, are being found less universal than had been thought. The view of Oppel (1856, etc.) that ammonite zones in all parts of the world follow in an identical succession, and the expectation that graptolite zones are equally regular and world-wide, have proved exaggerations; Dr. Spath has pointed out that the sequence of zonal ammonites differs in different basins. Geologists were once confident that the gaps in the geological column in Europe would be filled by discoveries elsewhere; such terms as Perrno-Carboniferous, Permo-Triassic, etc., expresised the hope that the beds thus named would fill gaps in the European sequence. Most of these strata have been found to correspond in time with those known in Europe Extra-European stratigraphy has shown the world-wide range of the geological systems.

\section{The Geological Leaders of the Four QUARTER-CENTURIES.}

My impression is that from 1830 until 1855 the true prophet of geology was Lyell, with his establishment of the mobility of the land and the uniformity of geological processes. From 1855 until 1880 the main advance was Darwin's establishment of evolution, which enabled fossils to be interpreted more intelligently and reliably. About 1880 the geologists of the United States revealed phenomena in their western mountains which showed that the yardstick reliable in north-western Europe and the Atlantic States of America was not applicable everywhere. The United States Geological Survey began its great influence about 1880 . Nevertheless, despite the powerful stimulus of North America on geological thought in the third quarter of the past century, the most profound individual influence was that of E. Suess.

The last quarter-century is still too near for reliable appreciation of its achievements; but among the fundamental advances have been those revealing the structure of the inner earth, and especially the interpretation of earthquakes, in which the pioneer was John Milne. The recent study of ore-deposits confirms the evidence from earthquakes that the core of the earth is surrounded by concentric shells and that the metallic ores arise from the shell below the plutonic rocks as gases and solutions. The geology of mineral fields and the extension to most of the younger mountain ranges of the world of the thrustplanes which, though early recognised in mining, were first demon. strated in stratigraphy by Lapworth in the northwest of Scotland, have proved that fold-mountains are formed along belts of compression.

No. 3238, VoL. 128] 